\title{
Penyajian Data Dalam Tabel Distribusi Frekuensi Dan Aplikasinya Pada Ilmu Pendidikan
}

\author{
Abdul Wahab ${ }^{\mathrm{a}, 1}$, Akhmad Syahid $^{\mathrm{a}, 2}$, Junaedi $^{\mathrm{b}, 3}$ \\ anniversitas Muslim Indonesia, 'Institut Agama Islam Darul Da'wah Wal Irsyad Polewali Mandar \\ 1abdulwahab79@umi.ac.id, 2akhmad.syahid@umi.ac.id, 3junaedi@ddipolman.ac.id
}

\begin{abstract}
Abstrak
Masih banyak kalangan mahasiswa yang berlatar belakang ilmu pendidikan khususnya pendidikan dasar, belum memahami penyusunan tabel distribusi frekuensi, oleh karena itu penulis mencoba menulis materi distribusi frekuensi. Jenis penulisan ini adalah bersifat studi literatur dan bertujuan untuk mempelajari distribusi frekuensi dan aplikasinya pada ilmu pendidikan. Fokus pembahasan dalam penulisan ini adalah menjabarkan (1) definisi distribusi frekuensi, (2) istilah-istilah dalam distribusi frekuensi, (3) langkah-langkah menyusun daftar distribusi frekuensi, (4) jenis-jenis tabel distribusi frekuensi, dan (5) aplikasinya dalam ilmu pendidikan. Hasil pembahasan yang diperoleh adalah (1) uraian tentang definisi distribusi frekuensi, (2) uraian istilah-istilah dalam distribusi frekuensi, (3) langkah-langkah membuat daftar distribusi frekuensi, (4) jenis-jenis tabel distribusi frekuensi, dan (5) aplikasinya terhadap data hipotetik.
\end{abstract}

\section{Kata Kunci: Distribusi frekuensi,Frekuensi Relatif, Frekuensi Kumulatif}

\section{Pendahuluan}

Apabila ingin melaksanakan kegiatan pengumpulan data statistika, maka seyogyanya akan mendapatkan kumpulan data angka yang kondisinya teracak, berserak dan merupakan bahan kajian yang sifatnya masih kasar atau mentah, karena kumpulan angka dengan kondisi itu belum akan mendapatkan atau memberikan informasi dengan ringkas dan jelas tentang karakteristik yang dimiliki kumpulan data tersebut.

Salah satu tugas dari statistik sebagai ilmu pengetahuan ialah menyajikan data angka yang telah berhasil dikumpulkan dengan teratur, jelas, ringkas, mudah dimengerti, hingga dengan secara jelas dapat memberikan deskripsi yang tepat mengenai ciri atau sifat yang terkandung di dalam data tersebut.

Kata data berasal dari kata datum yang artinya himpunan fakta yang digunakan dalam keperluan suatu diskusi atau pendapat. Materi fakta tersebut dapat berupa informasi, status, keterangan dan sebagainya, mengenai sesuatu atau sebagian objek yang di kumpulkan sendiri oleh periset dari sumber lain, seperti lembaga, publikasi, atau hasil riset orang lain.

Kegiatan riset tidak terlepas dari keberadaan data yang merupakan bahan baku informasi sebagai deskripsi khusus tentang obyek riset. Data merupakan kenyataan atau fakta empiris yang dihimpun oleh periset untuk kepentingan menyelesaika permasalahan dalam riset, data riset dapat berasal dari berbagai sumber yang dihimpun dengan memakai bermacam metode sepanjang kegiatan riset berlangsung.

Agar bisa di analisis data angka, data itu disusun lebih dahulu dengan sistematik yang dapat diselesaikan dengan berbagai cara. Jika data yang dipunyai terdiri dari banyak observasi, maka tidak dapat langsung memperoleh informasi tersebut. Untuk memudahkan hal tersebut, data disusun kedalam distribusi frekuensi. 


\section{Metode}

Metode penulisan ini bersifat studi literatur yang menjabarkan tentang konsep distribusi frekuensi dan aplikasnya pada ilmu pendidikan.

\section{Hasil dan Pembahasan}

Pada bagian ini akan di jabarkan konsep distribusi frekuensi yang dimulai dengan arti distribusi frekuensi, istilah dalam tabel distribusi frekuensi, langkah penyusunan tabel distribusi frekuensi, jenis tabel distribusi frekuensi, dan aplikasinya pada data ilmu pendidikan.

\subsection{Arti Distribusi Frekuensi}

Distribusi frekuensi merupakan rangkaian data angka menurut kuantitasnya dan atau kualitasnya (kategori). Rangkaian data angka menurut kuantitasnya disebut distribusi frekuensi kuantitatif, sebaliknya data yang disusun menurut kualitasnya (kategori) disebut distribusi frekuensi kualitatif. Contoh sederhana data kuantitatif adalah data yang mencakup tentang hasil belajar, prestasi belajar, jumlah siswa dan lain sebagainya. Sedangkan contoh data kualitatif ialah data mengenai jenis kelamin, jenis pekerjaan, tingkat pendidikan, status pernikahan dan sebagainya.

Tabel merupakan alat penyajian data statistika yang berbentuk baris dan kolom, dengan demikian, Tabel Distribusi Frekuensi dapat di artikan sebagai alat penyajian data statistik yang berbentuk kolom dan lajur yang di dalamnya dimuat angka yang dapat menggambarkan pembagian frekuensi dari variabel yang sedang menjadi objek riset.

\subsection{Istilah-istilah dalam Tabel Distribusi Frekuensi}

Dalam tabel distribusi frekuensi dikenal beberapa istilah berikut:

a. Kelas Interval

Kelas Interval adalah interval mengandung kelas. Biasanya dalam tabel distribusi frekuensi terdiri dair beberapa kelas, secara umum 5 (lima) sampai 15 (limabelas) kelas.

b. Ujung kelas

Ujung kelas adalah nilai ujung setiap kelas dalam distribusi yang digunakan sebagai pedoman untuk memasukkan angka-angka hasil observasi ke dalam kelas. Ada dua ujung dalam setiap kelasnya yaitu ujung bawah kelas dan ujung atas kelas.

c. Batas kelas

Batas kelas ialah angka yang diperoleh dengan cara nilai-nilai ujung kelas dikurangi atau ditambah dengan tingkat ketelitian yang digunakan. Dalam hal ini tingkat ketelitian data yang digunakan tergantung pada pencatatan datanya. Jika data yang digunakan ditulis dalam bilangan bulat, maka tingkat ketelitian datanya sebesar 0.5. jika data yang digunakan ditulis dalam bilangan satu desimal, maka tingkat ketelitian datanya 0.05 , dua angka desimal tingkat ketelitian datanya 0.005 dan seterusnya. Ada dua batas kelas dalam setiap interval kelasnya yaitu batas bawah kelas dan batas atas kelas interval. Bilangan-bilangan untuk batas bawah kelas didapat dari nilai-nilai ujung bawah kelas dikurangi dengan ketelitian data, sedangkan untuk batas atas kelas ditambah dengan ketelitian datanya.

d. Nilai tengah

Nilai tengah adalah rata-rata hitung dari kedua ujung kelasnya. Cara menghitungnya:

$$
\text { Nilai tengah }=\frac{1}{2} \text { (ujung bawah kelas }+ \text { ujung atas kelas) }
$$

e. Panjang kelas

Panjang kelas ialah angka yang diperoleh dari perbedaan selisih antara kedua batas kelasnya. 


\subsection{Menyusun Tabel Distribusi Frekuensi}

Menyusun tabel distribusi frekuensi yang panjang kelas yang sama, dilakukan langkahlangkah sebagai berikut:

a. Menentukan Rentang (R).

$$
\text { Rentang }(R)=\text { Nilai Maksimum }- \text { Nilai Minimum }
$$

b. Menentukan Banyak Kelas (B). Banyak kelas digunakan paling sedikit 5 kelas dan paling banyak 15 kelas, Cara lain untuk $n$ berukuran besar $n \geq 100$ dengan menggunakan aturan Sturges, yaitu:

$$
\text { Banyak kelas }(B)=1+3,3 \log n
$$

c. Menentukan panjang kelas (P), yaitu hasil bagi Rentang dengan Banyaknya Kelas dengan menggunakan rumus:

$$
\text { Panjang kelas }(P)=\frac{\text { Rentang }}{\text { Banyak kelas }}
$$

d. Menentukan ujung- ujung kelas untuk setiap kelas intervalnya. Dalam menentukan ujung-ujung kelas yang harus diperhatikan ialah menentukan nilai ujung bawah untuk kelas interval yang pertama. terdapat dua kemungkinan yang dapat dilakukan yaitu: nilai ujung bawah kelas interval pertama dapat mengambil nilai data yang terkecil atau nilai data yang lebih kecil dari nilai data yang terkecil.

e. Memasukkan semua data kedalam masing-masing kelas interval, menggunakan kolom turus/tally.

f. Menuliskan nomor dan judul tabel serta uraian dan sumber data yang didapat

\subsection{Jenis-jenis Tabel Distribusi Frekuensi}

Dalam distribusi frekuensi dikenal tiga jenis tabel distribusi frekuensi yaitu tabel distribusi frekuensi relatif, tabel distribusi frekuensi kumulatif dan tabel distribusi frekuensi relatif kumulatif.

\section{a. Tabel Distribusi Frekuensi Relatif}

Tabel distribusi frekuensi relatif adalah sebuah tabel yang berisi nilai-nilai data, dengan nilai-nilai tersebut dikelompokkan ke dalam interval-interval kelas dan tiap interval kelasnya masingmasing mempunyai bilangan frekuensi dalam bentuk persentase. Frekuensi relatif masing-masing kelas diperoleh dengan membagi frekuensi kelas dengan frekuensi totalnya.

b. Tabel Distribusi Frekuensi Kumulatif

Tabel distribusi frekuensi kumulatif adalah sebuah tabel yang diperoleh dari tabel distribusi frekuensi dengan frekuensinya dijumlahkan selangkah demi selangkah. Ada dua jenis tabel distribusi frekuensi kumulatif yaitu tabel distribusi frekuensi kumulatif "kurang dari" dan tabel distribusi frekuensi kumulatif "lebih dari".

c. Tabel Distribusi Frekuensi Relatif Kumulatif

Tabel distribusi frekuensi relatif kumulatif merupakan sebuah tabel yang diperoleh dari tabel distribusi frekuensi relatif dengan frekuensinya dalam bentuk persentase dijumlahkan selangkah demi selangkah. Ada dua macam tabel distribusi frekuensi relatif kumulatif yaitu tabel distribusi frekuensi relatif kumulatif "kurang dari" dan tabel distribusi frekuensi relatif kumulatif "lebih dari".

\subsection{Aplikasi pada Ilmu Pendidikan}

Berikut ini diberikan contoh penyusunan tabel distribusi frekuensi.

Contoh 1:

Data berikut merupakan data nilai ujian mata kuliah statistik untuk 80 orang mahasiswa di suatu perguruan tinggi, susunlah ke dalam tabel distribusi frekuensi! 


\begin{tabular}{llllllllll}
\hline 35 & 57 & 67 & 71 & 74 & 77 & 81 & 84 & 88 & 92 \\
38 & 58 & 67 & 71 & 74 & 78 & 81 & 85 & 88 & 93 \\
43 & 59 & 68 & 71 & 74 & 79 & 81 & 86 & 90 & 93 \\
45 & 60 & 68 & 72 & 74 & 79 & 82 & 86 & 90 & 93 \\
47 & 61 & 70 & 72 & 75 & 80 & 82 & 87 & 91 & 94 \\
50 & 61 & 70 & 72 & 75 & 80 & 83 & 88 & 91 & 95 \\
51 & 65 & 70 & 73 & 76 & 80 & 83 & 88 & 91 & 96 \\
54 & 66 & 70 & 73 & 76 & 80 & 83 & 88 & 92 & 97 \\
\hline
\end{tabular}

Penyelesaian:

a. Menentukan rentang, yaitu nilai maksimum dikurangi nilai minimum.

$\mathrm{R}=$ nilai maksimum - nilai minimum $=97-35=62$

b. Menentukan banyak kelas interval dengan menggunakan aturan Sturges, $\mathrm{n}=80$, yaitu:

$$
\begin{aligned}
\text { Banyak kelas } & =1+3,3 \log n \\
& =1+3,3 \log 80 \\
& =1+3,3 \times 1,903 \\
& =1+6,28 \\
& =7,28
\end{aligned}
$$

Jumlah kelas yang digunakan bisa 7 atau 8 kelas (dipilih jumlah kelas sebanyak 7)

c. Menentukan panjang kelas

$$
\begin{aligned}
\text { Panjang kelas }= & \frac{\text { Rentang }}{\text { Banyak kelas }} \\
& =\frac{62}{7} \\
& =8,86
\end{aligned}
$$

Panjang kelas interval bisa di gunakan 8 atau 9 (dipilih panjang kelas interval 9)

d. Menentukan ujung-ujung kelas

Jika ditentukan jumlah kelas 7 dan panjang kelas 10, maka di peroleh ujung-ujung kelas dengan ujung bawah kelas interval kelas yang pertama 34 dan memasukkan data ke dalam masingmasing kelas interval sehingga diperoleh tabel berikut:

Tabel 1. Nilai ujian statistika 80 mahasiswa dalam bentuk tally

\begin{tabular}{clc}
\hline Nilai Data & \multicolumn{1}{c}{ Tally } & Frekuensi \\
\hline $35-43$ & III & 3 \\
$44-52$ & IIII & 4 \\
$53-61$ & IIIII II & 7 \\
$62-70$ & IIIII IIIII & 10 \\
$71-79$ & IIIII IIIII IIIII IIIII & 20 \\
$80-88$ & IIIII IIIII IIIII IIIII II & 22 \\
$89-97$ & IIIII IIIII II & 14 \\
\hline Jumlah & & 80 \\
\hline
\end{tabular}

e. Menuliskan judul tabel serta catatan dan sumber data diperoleh.

Tabel 2. Nilai ujian statistika 80 mahasiswa dalam bentuk distribusi frekuensi 


\begin{tabular}{cc}
\hline Nilai Data & Frekuensi \\
\hline $35-43$ & 3 \\
$44-52$ & 4 \\
$53-61$ & 7 \\
$62-70$ & 10 \\
$71-79$ & 20 \\
$80-88$ & 22 \\
$89-97$ & 14 \\
\hline Jumlah & 80
\end{tabular}

Catatan: Sumber: data nilai statistika dari 80 orang mahasiswa

Contoh 2.

Dari penyelesaian Contoh 1. maka bentuk tabel distribusi frekuensi relatif nilai ujian statistika untuk 80 orang sebagai berikut:

Tabel 3. Distribusi Frekuensi Relatif, Nilai ujian statistika 80 mahsiswa

Contoh 3.

\begin{tabular}{cc}
\hline Nilai Data & \% Relatif \\
\hline $35-43$ & 3,8 \\
$44-52$ & 5,0 \\
$53-61$ & 8,7 \\
$62-70$ & 12,5 \\
$71-79$ & 25,0 \\
$80-88$ & 27,5 \\
$89-97$ & 17,5 \\
\hline Jumlah & 100 \\
\hline
\end{tabular}

Perhatikan kembali penyelesaian Contoh 1. maka diperoleh distribusi frekuensi kumulatif "kurang dari" dan distribusi frekuensi kumulatif "lebih dari" adalah:

Tabel 4. Distribusi frekuensi kumulatif, nilai ujian statistika 80 mahasiswa

\begin{tabular}{cccc}
\hline \multicolumn{2}{c}{ Kurang Dari } & \multicolumn{2}{c}{ Lebihi Dari } \\
\hline Nilai Data & Frekuensi & Nilai Data & Frekuensi \\
\hline$<35$ & 0 & $>34$ & 80 \\
$<44$ & 3 & $>43$ & 77 \\
$<53$ & 7 & $>52$ & 73 \\
$<62$ & 14 & $>61$ & 66 \\
$<71$ & 24 & $>70$ & 56 \\
$<80$ & 44 & $>79$ & 36 \\
$<89$ & 66 & $>88$ & 14 \\
$<98$ & 80 & $>97$ & 0 \\
\hline
\end{tabular}

Contoh 4.

Dari penyelesaian Contoh 1. Maka diperoleh frekuensi relatif kumulatif "kurang dari" dan "lebih dari" adalah:

Tabel 5. Distribusi frekuensi relatif kumulatif nilai tes 80 siswa

\begin{tabular}{cccc}
\hline \multicolumn{2}{c}{ Kurang Dari } & \multicolumn{2}{c}{ Lebih Dari } \\
\hline Nilai Data & $\%$ Kumulatif & Nilai Data & $\%$ Kumulatif \\
\hline$<35$ & 0 & $>34$ & 100 \\
\hline
\end{tabular}




\begin{tabular}{cccc}
\hline$<44$ & 3,8 & $>43$ & 96,2 \\
$<53$ & 8,8 & $>52$ & 91,2 \\
$<62$ & 17,5 & $>61$ & 82,5 \\
$<71$ & 30,0 & $>70$ & 70,0 \\
$<80$ & 55,0 & $>79$ & 45,0 \\
$<89$ & 82,5 & $>88$ & 17,5 \\
$<98$ & 100 & $>97$ & 0 \\
\hline
\end{tabular}

Contoh 5.

Diberikan data tentang skor hasil belajar 50 mahasiswa yang mengikuti mata kuliah pengantar statistika pendidikan di suatu perguruan tinggi.

\begin{tabular}{llllllllll}
\hline 45,8 & 46,7 & 49,0 & 50,5 & 45,2 & 42,9 & 45,1 & 49,7 & 53,0 & 55,5 \\
48,4 & 49,4 & 46,6 & 50,5 & 51,5 & 51,2 & 49,0 & 49,4 & 59,1 & 60,4 \\
50,9 & 42,3 & 52,1 & 50,3 & 48,5 & 50,8 & 51,7 & 55,3 & 46,7 & 49,7 \\
54,9 & 56,9 & 54,0 & 52,3 & 47,7 & 56,2 & 55,0 & 53,7 & 50,2 & 51,7 \\
54,8 & 56,4 & 55,0 & 51,3 & 59,3 & 58,8 & 55,2 & 57,0 & 60,4 & 56,3 \\
\hline
\end{tabular}

Susunlah ke dalam tabel distribusi frekuensi, di lanjutkan dengan mencari tabel distribusi frekuensi relatif, dan tabel distribusi frekuensi kumulatif, serta tabel distribusi frekuensi relatif kumulatif

\section{Penyelesaian}

a. Menentukan Rentang (R)

$$
\begin{aligned}
R & =\text { nilai maksimum }- \text { nilai minimum } \\
& =60,4-42,3 \\
& =18,1
\end{aligned}
$$

b. Menentukan Banyak kelas

$$
\begin{aligned}
B & =1+3,3 \log 50 \\
& =1+3,3 \times 1,699 \\
& =1+5,61 \\
& =6,61
\end{aligned}
$$

Banyak kelas boleh di ambil 6 atau 7 (dipilih 7 kelas)

c. Menentukan Panjang kelas

$$
P=\frac{18,1}{7}=2,58
$$

Panjang kelas diambil 2,5

d. Menentukan ujung kelas

Di tentukan banyak kelas 7 dan panjang kelas 2,5; maka ujung bawah kelas interval pertama di ambil adalah 42,3 dan memasukkan ke dalam kelas interval masing-masing

Tabel 6. Skor hasil belajar 50 mahasiswa dalam bentuk tally

\begin{tabular}{clc}
\hline Skor & \multicolumn{1}{c}{ Tally/turus } & Frekuensi \\
\hline $42,3-44,8$ & II & 2 \\
\hline $44,9-47,4$ & IIIII I & 6 \\
\hline $47,5-50,0$ & IIIII IIII & 9 \\
\hline $50,1-52,6$ & IIIII IIIII III & 13 \\
\hline $52,7-55,2$ & IIIII III & 8 \\
\hline $55,3-57,8$ & IIIII II & 7 \\
\hline $57,9-60,4$ & IIIII & 5 \\
\hline
\end{tabular}


e. Menuliskan judul tabel, maka terbentuklah tabel distribusi frekuensi

Tabel 7. Skor hasil belajar 50 mahasiswa dalam bentuk distribusi frekuensi

\begin{tabular}{cc}
\hline Skor & frekuensi \\
\hline $42,3-44,8$ & 2 \\
\hline $44,9-47,4$ & 6 \\
\hline $47,5-50,0$ & 9 \\
\hline $50,1-52,6$ & 13 \\
\hline $52,7-55,2$ & 8 \\
\hline $55,3-57,8$ & 7 \\
\hline $57,9-60,4$ & 5 \\
\hline Jumlah & 50
\end{tabular}

Sumber: data skor hasil belajar 50 mahasiswa

Selanjutnya tabel distribusi frekuensi relatif

Tabel 8. Skor hasil belajar 50 mahasiswa dalam bentuk distribusi frekuensi relatif

\begin{tabular}{cc}
\hline Skor & \% relatif \\
\hline $42,3-44,8$ & $2 / 50 \times 100=4$ \\
\hline $44,9-47,4$ & 12 \\
\hline $47,5-50,0$ & 18 \\
\hline $50,1-52,6$ & 26 \\
\hline $52,7-55,2$ & 16 \\
\hline $55,3-57,8$ & 14 \\
\hline $57,9-60,4$ & 10 \\
\hline Jumlah & 100 \\
\hline
\end{tabular}

Selanjutnya tabel distribusi frekuensi kumulatif

Tabel 9. Skor hasil belajar 50 mahasiswa dalam bentuk distribusi frekuensi kumulatif "kurang dari" dan "lebih dari"

\begin{tabular}{cccc}
\hline \multicolumn{2}{c}{ Kurang dari } & \multicolumn{2}{c}{ Lebih dari } \\
\hline Skor & Frekuensi & Skor & Frekuensi \\
\hline$<=42,25$ & 0 & $>=42,25$ & 50 \\
$<=44,85$ & 2 & $>=44,85$ & 48 \\
$<=47,45$ & 8 & $>=47,45$ & 42 \\
$<=50,05$ & 17 & $>=50,05$ & 33 \\
$<=52,65$ & 30 & $>=52,65$ & 20 \\
$<=55,25$ & 38 & $>=55,25$ & 12 \\
$<=57,85$ & 45 & $>=57,85$ & 5 \\
$<=60,45$ & 50 & $>=60,45$ & 0 \\
\hline
\end{tabular}

Selanjutnya tabel distribusi frekuensi relatif kumulatif

Tabel 10. Skor hasil belajar 50 mahasiswa dalam bentuk distribusi frekuensi kumulatif "kurang dari" dan "lebih dari"

\begin{tabular}{cccc}
\hline \multicolumn{2}{c}{ Kurang dari } & \multicolumn{2}{c}{ Lebih dari } \\
\hline Skor & $\%$ Kumulatif & Skor & \% Kumulatif \\
\hline$<=42,25$ & 0 & $>=42,25$ & 100 \\
$<=44,85$ & 4 & $>=44,85$ & 96 \\
$<=47,45$ & 16 & $>=47,45$ & 84 \\
$<=50,05$ & 34 & $>=50,05$ & 66
\end{tabular}




$\begin{array}{lccc}<=52,65 & 60 & >=52,65 & 40 \\ <=55,25 & 76 & >=55,25 & 24 \\ <=57,85 & 90 & >=57,85 & 10 \\ <=60,45 & 100 & >=60,45 & 0\end{array}$

\section{Simpulan}

Dalam penulisan ini telah dikemukakan ide fundamental distribusi frekuensi, diantaranya terdapat 5 istilah dalam tabel distribusi frekuensi yaitu kelas interval, ujung kelas, batas kelas, nilai tengah, dan panjang kelas, langkah-langkah penyusunan tabel distribusi frekuensi di mulai dengan menentukan rentang, banyak kelas, panjang kelas, dan menentukan nilai kelas interval pertama serta memasukkanya ke dalam tabel distribusi frekuensi, terdapat 3 jenis distribusi frekuensi yaitu distribusi frekuensi relatif, distribusi frekuensi kumulaatif, dan distribusi frekuensi relatif kumulatif, serta di berikan contoh distribusi frekuensi kuantitatif dalam ilmu pendidikan. 


\section{DAFTAR PUSTAKA}

Herrhyanto, N. dan Hamid, A.H.M. 2008. Statistika Dasar. Universitas Terbuka: Jakarta.

Nasoetion, A.H. \& Rambe .A. 1984. Teori Statistika. Edisi kedua. Bhratara: Jakarta.

Sudijono, A. 2018. Pengantar Statistika Pendidikan. Depok: Rajawali Pers.

Sudjana. 1996. Metode Statistika. Edisi ke-6. Tarsito: Bandung.

Supranto, J. 2001. Statistik: Teori dan Aplikasi Jilid 2. Edisi ke enam. Erlangga: Bandung.

Tiro, M.A. 2007. Dasar-dasar Statistika. Edisi Revisi. Makassar: State University of Makassar Press.

Wibisono, Y. 2005. Metode Statistik. Gadjah Mada University Press: Yogyakarta.

Wahab, A. 2013. Statistika I: Dasar-dasar Statistika Deskriptif untuk Ilmu Pendidikan dan Sains. Edisi Pertama. Yogyakarta: Kaukaba Dipantara. 